\title{
CUSTOMER SATISFACTION DETERMINANTS IN NIGERIA TELECOMMUNICATION FIRMS: THE CASE OF CUSTOMER SUPPORT SERVICES AND ASSURANCE
}

\author{
BY \\ KENNETH C. ADIELE \\ LECTURER, DEPARTMENT OF MARKETING \\ FACULTY OF MANAGEMENT SCIENCES \\ RIVERS STATE UNIVERSITY OF SCIENCE AND TECHNOLOGY, \\ PORT HARCOURT, NIGERIA. \\ Adiele.kenneth@ust.edu.ng \\ $A N D$ \\ MIEBAKA, D. GREND. \\ LECTURER, DEPARTMENT OF MARKETING, \\ RIVERS, STATE POLYTECNIC.BORI, NIGERIA \\ Grend.miebaka@yahoo.com
}

\begin{abstract}
This study examines the effect of customer support services and service assurance on customer satisfaction. The study population was the five functional telecommunication companies registered and listed by the Nigeria Communication Commission (NCC) and the Corporate Affairs Commission (CAC). Data was generated from 200 customers of these mobile service providers which were randomly chosen. Out of the 200 distributed copies of structured questionnaire, 173 copies were returned and qualified for use. Descriptively, the study variables were presented and inferentially, the simple linear regression analysis was used in testing the various hypotheses. It was found that a significant relationship exist between customer support services, service assurance and customer satisfaction. The study therefore concluded that customer support services and service assurance affect customer satisfaction. Hence, the authors recommended that in order for the telecom service providers to enhance their level of customer satisfaction they should improve their service assurance while taking cognizance of customer support services since it significantly impacts on their level of customer satisfaction.
\end{abstract}

Keywords: Customer support services, service assurance and telecom customer satisfaction

\section{Council for Innovative Research}

Peer Review Research Publishing System

\section{Journal: Journal of Social Sciences Research}

Vol. 6, No. 1

Jssreditor.cir@gmail.com

www.jssronline.com 


\section{INTRODUCTION}

The Nigerian telecommunication industry has experienced phenomenal growth in its subscribers' base, making it a highly competitive sector. And in this strongly competitive and liberalized telecommunication industry, customers are able to choose among multiple service providers based on the level of satisfaction, affordability, and service quality of service providers. A major challenge facing telecommunication service providers in Nigeria today is the continuous growing competition and customers' expectation of service quality. Customer demand and competition are forcing firms to cut loose from the traditional customer satisfaction paradigm to adopt proactive strategies which will assist them to take the lead in the market place.

Telecommunication firms operating in Rivers State Nigeria are consequently put into lot of pressures due to increase in competition. Various strategies are formulated to retain the customers and the key of it is to increase the service quality level. Customer support services and service assurance are particularly essential in the telecommunication service context because it provides high level of customer satisfaction and hence becomes a key to competitive advantage (Ahmossawi, 2001). The effect of poor performance will be particularly dismal for the telecommunication industry in Nigeria due to increase cut throat competition, poor service quality delivery, customer support services, network switching which has the potency of affecting the national telecommunication infrastructure (Biljani, \& Jusuf, 2011).

Specifically, many problems now plague the performance of Nigerian Telecommunication industry such as rising cost of energy, free stoppage of telecommunication operations. At the firm level is low customer patronage, lack of customer satisfaction, low market share, low profit margins etc.

Several studies have been conducted to attempt to understand customer support services and service assurance as antecedents to customer satisfaction of mobile service customers (for example Kim, Park \& Jeong, 2004; Lai 2004; Lin \& Wang, 2006; Turel \& Sorento, 2006; Wang \& Liao, 2007). Most of these studies emphasize that customer loyalty and the analysis of factors affecting it are important for the success of mobile service firms. Furthermore, they agree that customer satisfaction facilitates the attainment of mobile service provider's economic success. Nevertheless, the aforementioned studies were conducted in countries other than Nigeria and studied Short Message Services (SMS), Data Services (DS), Mobile Instant Messages (MIS); other than Mobile Call Services (MCS). There seem to be a dearth of empirical literature on the effect of customer support services and service assurance and customer satisfaction of Nigeria's mobile call service. Since foreign markets have different levels of market development and distinct consumer behaviour, those previous studies may provide limited application to Nigeria's mobile call services. As a big developing country, Nigeria's mobile market has some uniqueness (Adetunji, 2006 \& Bisong 2006).

Thus, a user's perception of service quality as an antecedent to customer satisfaction in China may differ from that found in other studies. Moreso, among the article search for past studies on the relationship between service quality and customer satisfaction most studies adopted the SERV QUAL model with little or no modification. Although the model was not able to address all the problems in the service industry since every service sector is expected to have its unique characteristics, and thus a proposed model is developed to fill the gap which the SERV QUAL model could not do especially in the telecommunication industry. In other words, there is need to replicate the study in Nigeria business environment with the same or different outcomes; thus creating a knowledge gap. Therefore, our point of departure is to ascertain the impact of customer support services and service assurance on customer satisfaction of telecommunication firms in Rivers State, Nigeria. A model depicting the relationship between the predictor variables and the criterion variable is presented in figure 1.

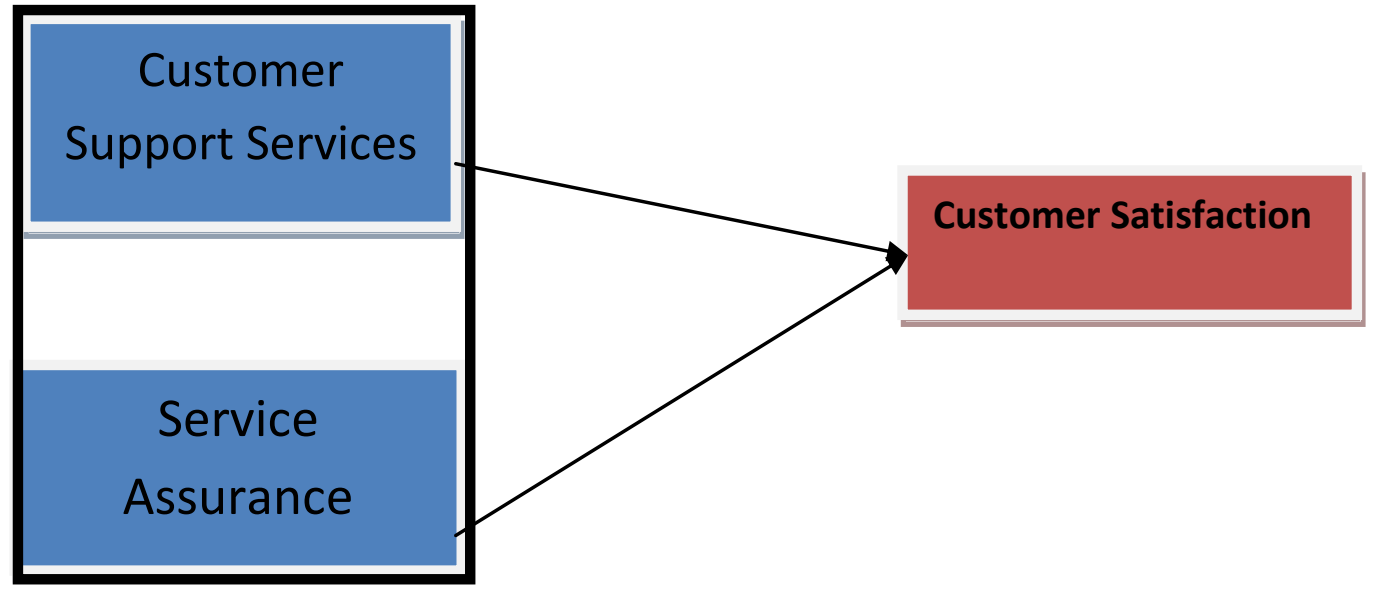

FIGURE. 1: THE CONCEPTUAL FRAMEWORK OF CUSTOMER SUPPORT SERVICES, SERVICES ASSURANCE AND CUSTOMER SATISFACTION.

Source: Literature, 2014.

\section{THEORETICAL FRAMEWORK}




\section{CUSTOMER SATISFACTION}

Customer satisfaction is the primary mental state of customer which comprises two things: (1) Expectation before purchase, and (2) Perception about performance after purchase (Oliver 2000; \& Satendra et al, 2011). Customer satisfaction can be defined using the transaction-specific perspective or cumulative perspective. The transaction perspective indicates that customer satisfaction is the evaluation based on the recent purchase experiences (Boulding et al, 2000). Compared with the transaction-specific perspective, the cumulative perspective stresses overall evaluation, indicating that evaluation of customer satisfaction should be based on all the purchase experiences of the customer disregarding any specific purchase experience (Guo et al, 2009). Parasuraman et al, (1988) argued that the cumulative perspective is more capable of evaluating the service performance of firms more effectively in predicting consumers' postpurchase behaviours (Wang et al, 2004).

Furthermore, customer satisfaction is a personal feeling of either pleasure or disappointment resulting from the evaluation of services provided by an organization to an individual in relation to expectations. Roberts (2009) defined customer satisfaction as "the degree to which a business's product or service performance matches up to the expectation of the customer. Customer satisfaction is influenced by expectations, perceived service and perceived quality (Turell and Sorento, 2006). Service providers frequently place a higher priority on customer satisfaction because it has been seen as a prerequisite to customer retention. Among the studies of customer satisfaction in the telecommunication and information technology industry, Lin and Wu (2011) revealed that customer satisfaction of mobile commerce is consumer's total response to the purchase experiences in a mobile commerce environment. Therefore, in this study, customer satisfaction is defined as the total consumption perception of consumers when using mobile value-added services.

\section{CUSTOMER SUPPORT SERVICES AND CUSTOMER SATISFACTION}

Customer service is the overall activity of identifying, satisfying and establishing customer needs. Several studies have found evidence that customer support service is positively correlated with customer satisfaction (Deng, Lu, Wei \& Zhang, 2009; Kim, Park \& Jeong, 2004). It is expected that higher level of customer support service in a company or industry should have a positive impact on the demand for any type of product or service. Customer support service is one of the most important ingredients of the marketing mix for products and services. High quality customer support service helps to create and enhance customer loyalty.

Customers today are not only interested in the products or service they are being offered but all the additional elements of service that they obtain from the greeting they receive when they enter a retail outlet, to the refund and help that they receive when they have complaint about a faulty product or poor service that they have paid for. Omotayo and Joachin (2008) in their study of relationship between customer service and customer retention in telecommunication industry noted that customer service enhances customer retention and satisfaction. In the telecommunication sector the service providers are focusing to enhance their relationship with customers by making their service quality more advanced and making more progress in customer-support service more viable in order to stay competitive in the market. Customer-support service is taken as core service to draw a strong bond of relationships with customers (Roos \& Edvardsson, 2008).

Furthermore, telecommunication core service normally comprises of networks which are facilitated through the use of mobile phones, broadband etc while support service normally perform the function of supporting and facilitating core services (Vargo \& Cusch, 2004a, b). The support services practically run by using sources like customer centres, internet, e-mail or telephone. The importance of the customer-support service for the service providers becomes crucial as whenever customers experience problem in services and values they usually and always contact and communicate with service providers (Roos \& Edwardson, 2008). Due to high competitive environment within telecom sector services, the firms continually improve and develop their operation of customer-support services.

Turel and Sorenko (2006) found a positive association between customer support service and the level of customer satisfaction. Lai (2004) provided evidence that customers get satisfied with a brand if they get all the needed customer support services accumulated in the very brand. Therefore, from the foregone discussion it seems that customer support service influences customer satisfaction; and on the basis of these arguments thus far, we propose that:

$\boldsymbol{H}_{\text {o1: }}$ There is no significant relationship between customer-support services and customer satisfaction in the telecommunication firms in Rivers State.

\section{SERVICE ASSURANCEAND CUSTOMER SATISFACTION}

Service assurance simply refers to the feelings of trust and confidence in customer's dealing with the organization. This reflects the workers' knowledge and experience and their ability to build self-confidence as well as confidence in the customers themselves. Moreso, service assurance focuses on the expertise of the employees about the multifaceted knowledge of the service offering, courtesy and their ability to instill faith and dependence in the service providers' competence (Moeed, et al, 2013). However, telecom staff are expected to have the competence to inspire trust and confidence among their customers about their ability in anticipating and meeting customer's needs (Muhammed \& Bilkis, 2012).

Service assurance (SA) is a procedure or set of procedures intended to optimize performance and provide management guidance in communication networks, media services and end user applications. Service assurance is an allencompassing paradigm that revolves around the idea that maximizing customer satisfaction inevitably maximizes the long-term profitability of an enterprise. 
However, the ability of cell phone service providers to offer better warranty terms conveys greater service assurance to buyers and can result in greater sales (Moeed et al, 2013). Service assurance is the ability to build trust in customers and showing courtesy every time. Moreso, it consists of polite behaviour of the staff, respect and gratitude for the customers and building confidence in them about the service (Parasuraman 1988). Moreso, it is the application of policies and processes by a communicating service provider (CSP) to ensure that services offered over networks meet a predetermined service quality level for an optimal subscriber experience. In addition, when customers are able to build and increase confidence in the ability of the cell phone service providers, it will ultimately lead to improved customer patronage, loyalty, retention and satisfaction. Lai (2004) found positive relationship between service assurance and customer satisfaction. Same findings were given by Cronin and Taylor (1992) in their research. According to Fornell (1992) a satisfied consumer helps the firm to increase market share and to sustain it, creates customer loyalty, shrink consumer price sensitivity and lessen other operating costs. From the discussions thus far, it appears that a relationship exist between service assurance and customer satisfaction and on the basis of the review of empirical literature we propose that:

$\boldsymbol{H}_{\text {o2: }}$ : There is no significant relationship between service assurance and customer satisfaction in the telecommunication firms in Rivers State.

\section{RESEARCH METHODOLOGY}

This study adopted a cross-sectional survey method and was restricted to cellular network service providers in Rivers State, and the study population is five mobile network companies, which are MTN, Globacom, Airtel, Etisalat and Visafone.

Primary data were drawn from these five companies which are functionally registered with the Corporate Affairs Commission (CAC) and the Nigeria Communication Commission (NCC) that operate on the 900/1800MHz spectrum. Two hundred (200) copies of structured questionnaire was our primary data collection device which were randomly distributed to the customers of the major GSM companies in Port Harcourt, Rivers State. Thus, the sample size for this study consisted of 200 respondents which were determined by convenience sampling. The choice of convenience sampling was necessitated by the unwilling attitude of the management of these companies to furnish the researcher with the actual number of registered subscribers/customer base in Rivers State. Furthermore, the sample size was mainly restricted to Port Harcourt which comprises of two major Local Governments: Obio/Akpor and Port Harcourt City Local Government Areas. These Local Government Areas are the largest in Rivers State in terms of population because of the heavy presence of oil and gas and other manufacturing companies, thereby making the area a commercial nerve centre.

However, the questionnaire was designed carefully by ensuring that the study objectives were considered. The questionnaire consists of three sections. Section A was merely an introduction which explained the purpose of the study and the questions were designed to elicit responses on demographic characteristics of respondents. Section B consists of twelve (12) questions designed to obtain responses on customer satisfaction determinants which are measured by two items adapted from Kim, et al (2004) and Parasuraman et al (1988) namely, customer support services and service assurance. The last part, Section $\mathrm{C}$ had three (3) questions bordering on customer satisfaction with the network providers in the industry. This was however measured by three items adapted from Cronin et al (2005), which are call/network quality, customer care services and price paid for network access/value added services. The questionnaire designs were adapted from current marketing literature and were modified to fit the content of the telecommunication industry. Thus, respondents were asked to indicate on a 5 point likert scale, their degree of agreement or disagreement with the statements. The questionnaire was pretested on 10 academia and 10 students of Rivers State University of Science and Technology, Port Harcourt and was revised on the basis of their comments.

Furthermore, the simple linear regression analysis was used to test the postulated hypotheses of the study and to ascertain the nature of relationship that exists between the predictor variables (customer support services and service assurance) and the criterion variable (customer satisfaction). The analysis was facilitated by the use of the Statistical Package for Social Sciences (SPSS Version, 20.0).

The Cronbach reliability test was used to ascertain or test for instrument reliability. From the analysis, the results were all above (0.70) threshold indicating that our research instrument was both reliable and valid (Nunnally, 1978). We therefore regard the items in the instrument as being internally related to the factors they are expected to measure. This is presented in table 1.

Table 1: Reliability Coefficients of Variables Measured

\begin{tabular}{|l|l|c|c|c|}
\hline S/No & \multicolumn{1}{|c|}{$\begin{array}{c}\text { Dimensions/measures of the } \\
\text { Study Variables }\end{array}$} & $\begin{array}{c}\text { Number of } \\
\text { Items }\end{array}$ & $\begin{array}{c}\text { Number of } \\
\text { Cases }\end{array}$ & $\begin{array}{c}\text { Cronbach's } \\
\text { Alpha }\end{array}$ \\
\hline 1. & Customer Support Services & 3 & 173 & 0.819 \\
\hline 2 & Assurance & 3 & 173 & 0.794 \\
\hline 3 & Customer satisfaction & 3 & 173 & 0.682 \\
\hline
\end{tabular}

Source: SPSS Version 20.0 output window 


\section{RESULTS AND DISCUSSION}

This section presents the results obtained from the test of postulated hypotheses and the discussion on the findings of the study. The first sub-section is devoted to the respondent's demographic and socio-economic characteristics, while the other section is devoted to factors affecting customer satisfaction.

Table 2: Respondent's Age bracket

\begin{tabular}{|c|c|c|c|c|c|}
\hline & & Frequency & Percent & Valid Percent & $\begin{array}{c}\text { Cumulative } \\
\text { Percent }\end{array}$ \\
\hline \multirow[t]{6}{*}{ Valid } & Under 20 & 6 & 3.5 & 3.5 & 3.5 \\
\hline & Between 20 - 29 & 51 & 29.5 & 29.5 & 32.9 \\
\hline & Between 30 - 39 & 80 & 46.2 & 46.2 & 79.2 \\
\hline & Between $40-49$ & 17 & 9.8 & 9.8 & 89.0 \\
\hline & 50 and Above & 19 & 11.0 & 11.0 & 100.0 \\
\hline & Total & 173 & 100.0 & 100.0 & \\
\hline
\end{tabular}

Source: SPSS Version 20.0 Output Window

Table 3: Respondents Educational Qualification

\begin{tabular}{|ll|r|r|r|r|}
\hline & & & & Cumulative \\
Valid & WAEC & Frequency & Percent & Valid Percent & \multicolumn{1}{c|}{ Percent } \\
\cline { 2 - 5 } & B.Sc. or its equivalent & 100 & 13.9 & 13.9 & 13.9 \\
& Post Graduate Degree & 38.8 & 57.8 & 71.7 \\
Others & 11 & 22.0 & 22.0 & 93.6 \\
& Total & 6.4 & 6.4 & 100.0 \\
\hline
\end{tabular}

Table 4:Gender of Respondents

\begin{tabular}{|c|c|c|c|c|c|}
\hline & & Frequency & Percent & Valid Percent & $\begin{array}{c}\text { Cumulative } \\
\text { Percent }\end{array}$ \\
\hline Valid & Male & 104 & 60.1 & 60.1 & 60.1 \\
\hline & Female & 69 & 39.9 & 39.9 & 100.0 \\
\hline & Total & 173 & 100.0 & 100.0 & \\
\hline
\end{tabular}

Source: $\quad$ SPSS Version 20.0 Output Window 
Table 5: Respondents Marital Status

\begin{tabular}{|c|c|c|c|c|c|}
\hline & & Frequency & Percent & Valid Percent & $\begin{array}{l}\text { Cumulative } \\
\text { Percent }\end{array}$ \\
\hline \multirow[t]{3}{*}{ Valid } & Single & 80 & 46.2 & 46.2 & 46.2 \\
\hline & Married & 93 & 53.8 & 53.8 & 100.0 \\
\hline & Total & 173 & 100.0 & 100.0 & \\
\hline
\end{tabular}

\section{Source: $\quad$ SPSS Version 20.0 Output Window}

Table 2, 34 , and 5 shows that (3.5\%) of the respondents are aged between 20 years and below; (29.5\%) are aged between $20-29,(46.2 \%)$ are between the ages of 30-39, which could be regarded as middle or productive age. However, $(9.8 \%)$ of the respondents are between the ages of $40-49$ while $(11 \%)$ are between the ages of 50 and above. In addition, $(13.9 \%)$ of the respondents had WAEC and other qualifications, $(57.8 \%)$ of them had B.Sc degree or its equivalent, (22\%) had post graduate degree while $(6.4 \%)$ of the respondents had one form of education or the other. This finding corroborates with the views of Liu (2008) that educational level of customers is one of the isolated variable acquisition and adoption of any service network. Moreso, the result showed that most of the subscribers of these network are males representing $(60.1 \%)$ while $(39.9 \%)$ are females. Furthermore, the result of our analysis revealed that $(54 \%)$ of the respondents were married while $(46 \%)$ were single.

Ho $0_{1}$ There is no significant relationship between customer support services and customer satisfaction in telecommunication firms in Rivers State.

Table 6: Linear relationship between customer support services and customer satisfaction

Model Summary
\begin{tabular}{|l|r|r|r|r|}
\hline Model & R & R Square & $\begin{array}{r}\text { Adjusted } \\
\text { R Square }\end{array}$ & $\begin{array}{r}\text { Std. Error of } \\
\text { the Estimate }\end{array}$ \\
\hline 1 & $.985^{\mathrm{a}}$ & .969 & .969 & .16534 \\
\hline
\end{tabular}

Source: SPSS Version 20.0 output window ANOVA

\begin{tabular}{|c|c|c|c|c|c|c|}
\hline \multicolumn{2}{|c|}{ Model } & $\begin{array}{l}\text { Sum of } \\
\text { Squares }\end{array}$ & $\mathrm{df}$ & Mean Square & $F$ & Sig. \\
\hline \multirow[t]{3}{*}{1} & Regression & 147.527 & 1 & 147.527 & 5396.728 & $.000^{\mathrm{a}}$ \\
\hline & Residual & 4.675 & 171 & .027 & & \\
\hline & Total & 152.202 & 172 & & & \\
\hline
\end{tabular}

Source: SPSS Version 20.0 output window

From the regression analysis result shown in table (6), it was found that in the model

summary table, the $R$ value is $(0.985)$, $R$ square $(0.969)$ adjusted $R$ square $(0.969)$ and the standard error of estimate is (0.16534). The large value of $R$ indicates a stronger relationship between the observed and predicted values of the variables.

In other words, the $\mathrm{R}$ value depict that customer support services accounted for $(98.5 \%)$ change in customer satisfaction while the $\mathrm{R}$ square is the proportion of variation in the dependent variable explained by the regression model. Hence, the large value of R-square (96.9\%) indicated that the model properly fits the data or population. Moreso, the value of adjusted $R(0.969)$ showed that the value of $R$ square more closely reflect the goodness of fit of the model in the population. Furthermore, the analysis of variance table (Anova) showed regression sum of square value of (147.527) which is higher than the residual sum of square value of (4.675). This implies that the model accounted for most of the variations in the dependent variable. Moreso, the $\mathrm{F}$ calculated value of (5396.728) is greater than the tabulated value of $(3.90)$ indicating a significant relationship. In addition, the significant value of $\mathrm{P}(0.000)$ is smaller than $(0.05)$ which means that the independent variable (customer support services) to a high extent accounted for the variations in the dependent variable 
customer satisfaction. Hence, we opined that there is a significant relationship between customer support services and customer satisfaction in telecommunication firms in Rivers State.

$\mathrm{Ho}_{2}:$ There is no significant relationship between service assurance and customer satisfaction in telecommunication firms in Rivers State.

Table 7: Linear relationship between service assurance and customer satisfaction

Model Summary
\begin{tabular}{|l|r|r|r|r|}
\hline Model & $\mathrm{R}$ & R Square & $\begin{array}{l}\text { Adjusted } \\
\text { R Square }\end{array}$ & $\begin{array}{r}\text { Std. Error of } \\
\text { the Estimate }\end{array}$ \\
\hline 1 & $.975^{\mathrm{a}}$ & .951 & .951 & .20897 \\
\hline
\end{tabular}

Source: SPSS Version 20.0 output

\begin{tabular}{|ll|r|r|r|r|r|}
\hline \multicolumn{1}{|c|}{ Model } & & Sum of & & & & \\
\hline 1 & & Squares & df & Mean Square & \multicolumn{1}{c|}{$\mathrm{F}$} & Sig. \\
\hline & Regression & 144.734 & 1 & 144.734 & 3314.302 & $.000^{\mathrm{a}}$ \\
& Residual & 7.468 & 171 & .044 & & \\
& Total & 152.202 & 172 & & & \\
\hline
\end{tabular}

Source: SPSS Version 20.0 output

From the regression analysis result shown in table (7), it was found that in the model summary table, the $R$ value is (0.975), R square (0.951) adjusted $R$ square (0.951) and the standard error of estimate $i(0.20897)$. The large value of $R$ indicates a stronger relationship between the observed and predicted values of the variables.

In other words, the $\mathrm{R}$ value depict that service assurance accounted for (97.5\%) change in customer satisfaction while the $\mathrm{R}$ square is the proportion of variation in the dependent variable explained by the regression model. Hence, the large value of $\mathrm{R}$-square $(95.1 \%)$ indicated that the model properly fits the data or population. Moreso, the value of adjusted $\mathrm{R}$ $(96.9 \%)$ showed that the value of $\mathrm{R}$ square more closely reflect the goodness of fit of the model in the population. Furthermore, the analysis of variance table (Anova) showed regression sum of square value of (144.734) which is higher than the residual sum of square value of (7.468). This implies that the model accounted for most of the variations in the dependent variable. Moreso, the $\mathrm{F}$ calculated value of (3314.302) is greater than the tabulated value of $(3.90)$ indicating a significant relationship. In addition, the significant value of $P(0.000)$ is smaller than $(0.05)$ which means that the independent variable (assurance) to a high extent accounted for the variations in the dependent variable customer satisfaction. Hence, we posit that there is a significant relationship between service assurance and customer satisfaction in telecommunication firms in Rivers State.

\section{DISCUSSION OF THE FINDINGS}

\section{Customer Support Service and Customer Satisfaction}

The result from our analysis in table 6 corroborates with the views of Roos and Edvardsson (2008) which opine that in the telecommunication sector, the service providers are focusing to enhance their relationship with customer by making their service quality more advanced and making more progress in customer-support service more viable in order to stay competitive in the market. They further opined that customer-support service is taking as a core service to draw a strong bond of relationships with customers. Based on the empirical review of literature thus far, we conclude that customer support services significantly affect customer satisfaction.

\section{Service assurance and Customer Satisfaction}

The findings of the study as depicted in table 7 agree with the views of Lai (2004) that a positive relationship exist between service assurance and customer satisfaction. This statement was further confirmed by Cronin and Taylor (1992) in their research. The ability of mobile phone service providers to offer better warranty terms conveys greater service assurance to buyers and can resulting greater sales (Moeed, et al 2013). From the forgone discussions from empirical literature and data analysis, we conclude that service assurance significantly affect customer satisfaction.

\section{CONCLUSION AND RESEARCH IMPLICATIONS}

Mobile telecommunication Operators (MTOs) are growing rapidly in Nigeria. Based on the experience of industry growth in the recent years, the researchers expect to see increase in mobile operator's in future. From the findings of this study, it 
could be concluded that customer support services, and service assurance are most predictors of customer satisfaction in the telecommunication industry. This suggests that all these factors must be improved if customer satisfaction is to be maximized and loyalty achieved. A customer support service is the most important factor that directly influences customer satisfaction. This implies that poor call quality and undependable customer service assurance are possible causes of dissatisfaction and therefore must be improved significantly for retention and satisfaction of valued customers.

As an emerging area of interest, telecommunication service providers should see the framework as an additional insight and attempt to evolve strategies aimed at retaining customers through satisfaction programs like improved customer care, guarantee of service, warranty of tangible products purchased, money refund offers in case of product/service failure as this will enhance trust and commitment and reduce switching attitude among customers in the telecommunication industry. In addition, the result of this study is instructive and has provided necessary insight to promote operation in the telecommunication industry. However, this study is limited to the fact that it was based on a cross sectional survey data obtained only from customers in Port Harcourt Rivers State. Further research should explore the entire Nigeria using a larger data set to enhance generalization.

\section{REFERENCES}

1. Adetunji, M. S. (2006). Investigating customer satisfaction in the service economy. Journal of Social and Management Services, 7(10), 210-226.

2. Al-Dararkah, H. A. (2006). Analyzing service quality in the UAE Islamic banks. Journal of financial service marketing, 8(2), 32-119.

3. Almossawi, M., (2001). Bank selection criteria employed by College students in Bahrain: an empirical analysis. International Journal of Bank Marketing 19(3), 115-125.

4. Biljana, A. \& Jusuf, Z. (2011). Measuring customer satisfaction with service quality using American customer satisfaction model (ACSI model). International Journal of Academic Research in Business and Social Sciences, 1(3), 232-258.

5. Bolton, R. N., \& Drew, J. H. (2005). A multistage model of customers' assessments of service quality, and value. Journal of Consumer Research, 17, 375-384.

6. Boulding, W., Kalra, A., Richard, S. \& Zeithaml, V. A. (2000). A dynamic process model of service quality: From expectations to managerial intentions. Journal of Marketing Research, 30(1), 7-27.

7. Cap Gemini (2003). Wireless phone users demand more than lower price plans according to German mobile cellular Telecommunications market. Telecommunication policy, 245-249.

8. Cavana, R. Y., Corbett, L. M., \& Lo, T. L. (2007). Developing zones of tolerance for managing passenger rail services quality. International Journal of Quality and Reliability Management, 24(1), 7-31.

9. Chae, M., Kim, H., \& Ryu, H. (2002). Information quality for mobile internet services: A theoretical model with empirical validation. Electronic markets, 12(1), 38-46.

10. Chion, J. S., \& Droge, C. (2006). Service quality, trust specific assets investment, and expertise: Direct style $6^{\text {th }}$ Edition and indirect effects in a satisfaction form of reference-loyalty framework. Journal of the Academy of Marketing Science, 34(4), 613-627.

11. Collier, J. E., \& Bienstock, C. C (2006). Measuring service quality in e-retailing. Journal of Service Research, 8(3), 260-275.

12. Consumer Report (2005). There are differences among major carriers. (Online) Available: http://www.wsjconsumer.Report/org/wsjreport59c.html (May 15, 2009).

13. Cronin, J. J., \& Taylor, S. A., (1992). Measuring service quality a re-examination and extension. The Journal of Marketing, 56(3), 55-68.

14. Cronin, J. J., Brady, M. K., \& Hult, G. T. M. (2005). Assessing the effects of quality, value and customer satisfaction on consumer behavioural intentions in service environments. Journal of Retailing, 76(2), 193-218.

15. Deng, Z., Lu, Y., Wed, K. K. \& Zhang, J. (2009). Understanding customer satisfaction and loyalty: An empirical analysis in the service sector. International Journal of Information Management, 30, 289-300.

16. Etuk, E. J. (2010). Business research method, concepts, processes, and application. University of Calabar: University of Calabar press Nigeria.

17. Fornell, C. (1992). A national customer satisfaction barometer: The Swedish experience. Journal of Marketing, $56,6-21$.

18. Gera J. L. (2011). Service quality and customer satisfaction: An empirical investigation in Indian Mobile Telecommunication Services. Marketing Management Journal, 18(2), 119-144.

19. Gerpott, T., Rams, W., \& Schindler., A., (2001). Customer retention, loyalty and satisfaction in the German Mobile Cellular telecommunications market. Telecommunication policy, 25(4), 249-269. 
20. Gronroos, C. (1994). From marketing mix to relationship marketing: Towards a paradigm shift in marketing. Journal of Management decision, 32(2), 4-20.

21. Guo, L., Xiao, J. J., \& Tang, C. (2009). Understanding the psychological process underlying satisfaction and retention in a relational service. Journal of Business Research, 62 1152-1159.

22. Hsu, H. (2006). An empirical study of website quality, customer value and customer

customer based on e-shop. The Business Review, 5(1), 190-193.

23. Ibok, N. I. (2008). The concept of satisfaction and its relevance to consumer behaviour: Implication for theory development. The Nigerian Accounting Horizon, 1(1), 208-218.

24. Johnson, M. D., \& Fornell, C. (2000). A framework for comparing customer satisfaction across individuals and product categories. Journal of Electronic Psychology, 12(2), 267-286.

25. Kassim, N. M. \& Abdullah, N. A. (2008). Customer loyalty in e-commerce study. Journal of electronic markets. 18(3), 275-290.

settings. An empirical

26. Kim, D. J., Ferrin, D. L., \& Rao, H. R. (2009). Trust and satisfaction, two stepping stones for successful commerce relationships: A longitudinal exploration. Information systems research, 20(2), 237-257.

27. Kim, H. S. \& Yoon, C. H., (2004). Determinants of subscriber churn and customer loyalty in the Korean mobile telephony market. Telecommunications policy, 28(9/10), 751-765.

28. Kim, M. K., Park, M. C., \& Jeong D. H. (2004). The effects of customer satisfaction and switching barrier on customer services. Journal of Total Quality Management, 9(6), 431-443.

29. Kotler, P. \& Armstrong G. (2010). Principles of marketing, $13^{\text {th }}$ edition. Pearson Education Inc., Upper Saddle River: New Jersey USA.

30. Kotler, P. (2003). Marketing management. Pearson education Inc.: New Jersey USA.

31. Kotler P., \& Keller, K. L. (2006). Marketing management $12^{\text {th }}$ Edition. Pearson Education Inc, New Jersey USA.

32. Kuo, C. T. (2003). Study of customer satisfaction of swimming pool-using Chung Cheng University's swimming pool. Journal of Physical Education,

the sample of National 49-68.

33. Kuo, Y. F. (2003). A study on service quality of community websites. Total Business Excellence, 14 (4), 461-473.

Quality Management and

34. Lai, T. L. (2004). Service quality and perceived values impact on satisfaction intention and short message services (SMS). International systems Frontiers, 6(4), 353368.

usage of

35. Lee, G. G., \& Lin, H. F. (2005). Customer perception of e-service quality in online shopping. International Journal of Retail and Distribution Management, 33 (2/3), 6161-176.

36. Lee, H., Lee, Y., \& Yoo, D. (2000). The determinants of perceived service quality and its relationship with satisfaction. Journal of Services Marketing. 14(3), 217-231.

37. Lee, J. \& Fredrick, L., (2001). The impact of switching costs on the customer satisfaction- loyalty link: Mobile phone services in France. Journal of Services Marketing, 15(1) 35-48.

38. Lin, J. S. C. \& Wu, C. Y. (2011). The role of expected future use in relationship based service retention. Managing service quality, 21(5), 535-551.

39. Moeed, A. S., Syeda, S. M., Asad, U. R., \& Saira, M. (2013). Service quality dimensions impact on customer satisfaction in telecom sector of Pakistan. Journal of Basic and Applied Science Research, 3(8), 27-34.

40. Mohamed, H. \& Shirley, L. (2009). Customer perception on service in Middle East: The case of Qatar. International Journal of Islamic and Middle Eastern finance and management, 2(4), 338-350.

41. Mohammed, B. U., \& Bilkis, A. (2012). Customer satisfaction in mobile phone services in Bangladesh: A survey research. Management and marketing. 20-34.

42. Njoku, A. T. (2008). What are the issues unsolved in consumer satisfaction question. Journal of Marketing Research, 32(8), 172-180.

43. Nunnally, J. C. (1978). Psychometric Theory (2 ${ }^{\text {nd }}$ ed.) New York: McGraw-Hill.

44. Oliver, R. L. (1997). Satisfaction: Behaviour Perspective on the Consumer, McGraw-Hill New York.

45. Oliver, R.L. (2000). Response determinants in satisfaction judgments. Journal of Consumer Research, 14, 495507.

46. Omotayo, O., \& Joachim, A. (2008). Customer Service in the retention of mobile phone users in Nigeria. African Journal of Business Management, 2(2), 026-031. 
47. Parasuraman, A., Zeithaml, V. A., \& Berry L. L. (1988). SERVQUAL: A multiple-Itemscale for consumer perceptions of service quality. Journal of Retailing, 64(1), $12-40$.

48. Parasuraman, A., Zeithaml, V. A., \& Berry, L.L. (1985). A conceptual model of service quality and its implications for future research. Journal of Marketing, 49, 41-50.

49. Park, C. H., \& Kim, Y. G. (2006). The effect of information satisfaction and relational benefit of consumers online shopping site commitments. Journal of Electronic Commerce in organization 4(1), 70-90.

50. Ribbink, D., Van, R. Liljander, A. C. R., \& Streukens, V. S. (2004). Comfort your online customers: quality, trust and loyalty on the internet. Managing Service Quality, 14, 446-456.

51. Roberts M. (2009). Customer retention strategies implemented by fast food outlets in the Guateng, Western Cape and Kwazulu-Natal provinces of South-Africa: A focus on African Journal of Marketing Management, 1(2), 70-80.

52. Roos, I., \& Edvardsson, B. (2008). Customer-support service in the relationship perspective. Managing Service Quality, 18(1), 87-107.

53. Saravanan, R \& Rao, K. S. P. (2007). Measuring service quality from the customer's perspective- An empirical study, Total Quality Management, 18(4) 435-449.

54. Satendra, T. \& Singh, A. P. (2011). Impact of service quality, customer satisfaction and trust on customer loyalty: A study with special reference to Telecommunication Company in Madhya Pradesh (India). Zenith international Journal of Business Economics and Management Research, 1(2), 66-78.

55. Spreng R. A., \& Mackoy, R. D. (2000). An empirical examination of a model of perceived service quality and satisfaction. Journal of Retailing, 72, 201-214.

56. Sureschandar, T. I. (2003). Banking service quality provided by commercial banks and customer satisfaction. American Journal of Scientific Research, 6(2), 68-83.

57. Tsoukatos, E \& Rand, G. K. (2006). Path analysis of perceived service quality, satisfaction and loyalty in Greek Insurance. Managing Service Quality 16(5), 501-519.

58. Tung, I. L. (2004). Service quality and perceived value's impact on satisfaction, intention and usage of short message service (SMS). Information systems frontiers, 6(4), 353- 368.

59. Turel, O. \& Sorento, A. (2006). Satisfaction with mobile services in Canada: An empirical investigation. Telecommunication policy, 30(6), 314-331.

60. Vargo, S. L., \& Lusch, R. F. (2004a). Evolving to a new dominant logic of marketing. Journal $68,1-17$.

61. Vargo, S. L., \& Lusch, R. F. (2004b). From goods to service(s): Divergences and Convergences of logics. Industrial Marketing Management, 37(3), 254-259.

62. Walfried, M. L., Chris, M., \& Robert, D. W. (2008). Service quality perspectives and satisfaction in private banking. Journal of Service Marketing, 14(3), 15-30.

63. Wang, Y., Lo, H. P., \& Yang, Y. (2004). An Integrated framework for service quality, customer value, satisfaction: Evidence from China's telecommunication industry. Journal of Information Systems Frontiers, 6(40), 325-340.

64. Wang, Y., Lo, H., \& Hui, Y. V. (2007). The antecedents of service quality and product quality and their influences on bank reputation: evidence from banking industry in China. Managing service quality, 13(1), 72-83.

65. Zeithaml, V. A., Berry, L.L., \& Parasuraman, A. (1996). The behavioural consequences of service quality. Journal of Marketing, 60(4), 31-46.

\section{APPENDIX 1 \\ LIST OF REGISTERED MAJOR TELECOMMUNICATION FIRMS IN RIVERS STATE, NIGERIA.}

1. MTN

2. GLOBACOM

3. AIRTEL

4. ETISALAT

5. VISAFONE

Source:Corporate Affairs Commission (CAC), Nigeria Communication Commission (NCC); Jidaw.com, 2009,

ALKtechafrica.com2013 